\title{
A multicity investigation on Fear of Crime
}

\author{
Andrea Pődör ${ }^{\text {a, }}$, László Zentai ${ }^{\text {b,* }}$ Zalán Hum ${ }^{\text {c }}$ \\ ${ }^{a}$ Institute of Geoinformatics, University of Óbuda, Alba Regia Technical Faculty, Székesfehérvár, Hungary; \\ podor.andrea@amk.uni-obuda.hu \\ ${ }^{b}$ ELTE Eötvös Loránd University, Institute of Cartography and Geoinformatics, Budapest, Hungary; \\ laszlo.zentai@elte.hu \\ ${ }^{c}$ surveyor; zalan.hum@gmail.com \\ * Corresponding author
}

\begin{abstract}
Fear of crime is a complex phenomenon, often not connected to the crime itself. It is sometimes influenced by other environmental factors, thus creating fear in the population. We examined fears of crime and their causes in seven different cities and municipalities in the present study. The primary data collection was an online questionnaire, which were then processed with various GIS software (ArcGIS, GeoDa). We then processed police statistics related to registered crimes committed. Finally, we compared questionnaires and police data using basic statistical methods.
\end{abstract}

Keywords: fear of crime, spatial analyses, GIS in public order

\section{Introduction}

In connection with the fear of crime, it should be emphasized that discomfort can also be developed due to unfavourable public safety (Mátyás et al, 2019, Tihanyi et al, 2020, Brunton-Smith, Sturgis, 2011, Skogan, Maxfield, 1980). In connection with the fear of crime, it is necessary to indicate those crimes types that may affect the fear: crime against a person, crime against property, economic crime, violent crime (Pődör, Dobos, 2014, Brantigam, Brantigam, 2010).

The current crime statistics are available on the official website of the $\mathrm{KSH}$, where it can be observed that recently and in the early 2000s, the total number of crimes show a decreasing trend. On the contrary researchers experience a standard level in the perception of fear of crime. (Mátyás et al, 2020).

The fact that the examination of criminal statistical data with GIS software can help to understand the correlations between environmental factors and fear of crime is wellresearched. (Chainey and Ratcfliff, 2013, Pödör 2015, Leitner and Kounadi, 2015, Kounadi et al.2015). For example, it can help crime prevention by planning optimal "safe routes" or even the calculation of police patrols (Mátyás, 2017), but GIS processing of fear of crime can lead to similarly valuable information.

The present study's main aim is to explore whether some spatial patterns can be recognized for "unsafe" areas and whether there is any correlation between crime and fear of crime.

The study covered seven cities: Dunaújváros, Miskolc, Székesfehérvár, Heves, Balmazújváros, Budapest, Nyíregyháza.

\section{Material and method}

To examine the topic, we have previously successfully created a web interface where people's opinions and comments can be tracked (http://bunmegelozes.amk.uniobuda.hu/).
Respondents provide their zip code (settlement ID), age, gender, and they draw their daily route. They can also write other comments. The completed data is collected in a central database. These can only be downloaded from the database with administrator privileges based on the specified time interval.

During the data acquisition, the data of the objects, attributes and geometries were extracted, which was a geojson file containing polygons and the corresponding data table.

Data collection took place between 2016 and 2019, at different times for each city. MSc students from the Faculty of Law Enforcement of the University of Public Service also participated in the data collection (Pődör, Zentai, Gál 2019).

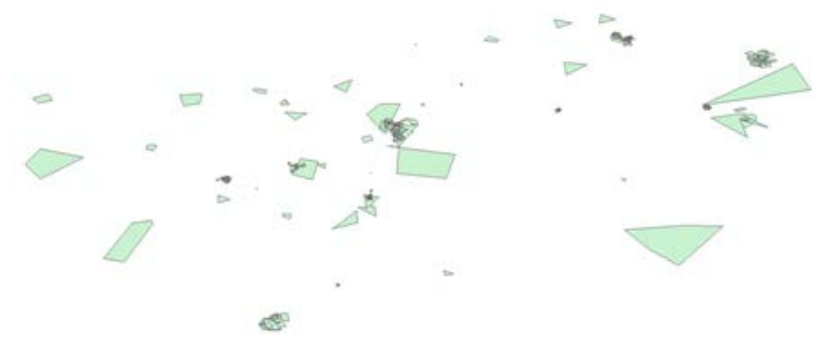

Figure 1. Raw polygons created by respondents for the whole country

Based on the available data, we selected those settlements for analysis (seven settlements) for which a sufficient amount of data of about 50 respondents was available at the time of processing (Figure 1).

During the processing, we created a 100x100 meter Grid model for each settlement. During the process, it was necessary to determine the extent of the grids. This is given by the edges of the extreme polygons per each city. We then calculated how many overlapping polygons fall within a grid. Fearful and safe places were examined separately. 
Registered crimes between 2016 and 2018 appeared as points on the maps. These were processed similarly. We used the same grid created for the fear of crime polygons and counted how many crimes fell into a grid during the study period.

In the case of registered crimes, we also conducted further investigations. Kernel Density calculates the density of point characteristics around each output raster cell (Silverman, 1986). With the help of Kernel Density, a raster map of all seven cities was created. We also examined the distribution of crimes using the optimized hotspot method.

In the case of optimized hotspot analysis, the points of a given crime or their weighted characteristics (points or polygons) are used to generate statistically significant hot and cold spots using Getis-Ord Gi statistics. It evaluates the characteristics of the input class to achieve optimal results. Getis-Ord assigns a numeric value to each territorial unit (Kanó, 2013).

We then examined the spatial correlation for both unsafe, safe places and crimes. The Global Moran's I method can be used to examine clustering.

Using a Pareto diagram, we examined the histogram of safe and unsafe areas.

Using GeoDa software, a standard deviation diagram can be created, examining the relationship between the two factors. You can create a chart in the software using ScatterPlot. We can draw conclusions about the nature of the stochastic relationship between the two factors and their strength. The value pairs are represented on the $\mathrm{x}$ and y coordinate axes, where we can draw conclusions about the nature and strength of the relationship from the point set's direction and density. Unfortunately, further studies are still needed because only correlation-based research does not explain the relationship between the two factors. ${ }^{1}$

The histogram representation mode, also known as a Pareto diagram, is suitable for observing the frequency distribution. It is practically very similar to a bar chart, except it is not suitable for displaying quantitative variables. We can read important information about the histogram's shape and extent, which can help us later if we want to perform statistical tests. Respectively, it is also an important condition that the data be normally distributed. ${ }^{2}$

\section{Results}

In the seven cities, we had altogether 908 respondents. We had $41 \%$ female and $59 \%$ male respondents. As Table 1 shows the majority of the respondent were coming from the younger generation, so the survey is not representative.

\begin{tabular}{|l|l|l|l|}
\hline Age & $\begin{array}{l}\text { Number of } \\
\text { respondents }\end{array}$ & $\begin{array}{l}\text { Female } \\
\text { respondents }\end{array}$ & $\begin{array}{l}\text { Male } \\
\text { respondents }\end{array}$ \\
\hline 22 & 42 & 15 & 27 \\
\hline 18 & 36 & 17 & 19 \\
\hline 19 & 36 & 18 & 18 \\
\hline 24 & 35 & 16 & 19 \\
\hline 21 & 34 & 13 & 21 \\
\hline 25 & 34 & 10 & 24 \\
\hline 29 & 34 & 17 & 17 \\
\hline 20 & 33 & 11 & 22 \\
\hline 23 & 30 & 11 & 19 \\
\hline 28 & 30 & 13 & 17 \\
\hline
\end{tabular}

Table 1 . Number of participants sorted by age (only the first ten age group are shown)

The majority of the respondents (34\%) used car, $28 \%$ of them used public transport, $12 \%$ used bicycle as means of transport, $24 \%$ of them walked.

We conducted several researches connected to fear of crime. Our experience is that the usual respondents draw one polygon for safe areas and one for unsafe places. In this study we experienced bigger dispersion between the participants as Table 2. shows.

\begin{tabular}{|l|l|}
\hline Metrics per respondents & \\
\hline Average Nr. of polygon & 3.51 \\
\hline Maximum Nr. of polygons & 34 \\
\hline Scattering & $\mathbf{2 . 2 5}$ \\
\hline
\end{tabular}

Table 2. Summary of completed questionnaires

\footnotetext{
1 “Scatter Chart (Correlation Chart)," [Online]. Available: http://www.leanforum.hu/index.php/szocikkek/178szörasdiagram-korrelacios-diagram. [Accessed on: 2010

2 „Histogram | SPSSABC.HU, ”[Online]. Available: https://spssabc.hu/diagram-keszitese/hisztogram/. [Accessed on: 0711 2020].
} 2020] 


\begin{tabular}{|l|l|l|l|}
\hline \multicolumn{1}{|c|}{ Town } & $\begin{array}{c}\text { Population } \\
\text { density } \\
\text { (Based on } \\
\text { the 2019 } \\
\text { survey) }\end{array}$ & $\begin{array}{c}\text { Most } \\
\text { common } \\
\text { crimes } \\
\text { (2016- } \\
\mathbf{2 0 1 8}\end{array}$ & $\begin{array}{c}\text { Number of } \\
\text { questionnaires } \\
\text { completed by } \\
\text { local residents }\end{array}$ \\
\hline Dunaújváros & $\begin{array}{l}864 \\
\text { person/km2 }\end{array}$ & $\begin{array}{l}\text { Theft } \\
(852)\end{array}$ & 147 \\
\hline Miskolc & $\begin{array}{l}673 \text { person } \\
/ \mathrm{km} 2\end{array}$ & $\begin{array}{l}\text { Theft } \\
(3509)\end{array}$ & 98 \\
\hline Székesfehérvár & $\begin{array}{l}564 \text { person } \\
/ \mathrm{km} 2\end{array}$ & $\begin{array}{l}\text { Theft } \\
(1474)\end{array}$ & 113 \\
\hline Heves & $\begin{array}{l}106 \text { person } \\
/ \mathrm{km} 2\end{array}$ & $\begin{array}{l}\text { Theft } \\
(642)\end{array}$ & 64 \\
\hline Balmazújváros & $\begin{array}{l}86 \text { person } \\
/ \mathrm{km} 2\end{array}$ & $\begin{array}{l}\text { Theft } \\
(181)\end{array}$ & 45 \\
\hline Budapest & $\begin{array}{l}3332 \\
\text { person } \\
/ \mathrm{km} 2\end{array}$ & $\begin{array}{l}\text { Theft } \\
(37036)\end{array}$ & 204 \\
\hline Nyíregyháza & $\begin{array}{l}436 \text { person } \\
/ \mathrm{km} 2\end{array}$ & $\begin{array}{l}\text { Theft } \\
(2293)\end{array}$ & 57 \\
\hline
\end{tabular}

Table 3. Summary of settlements based on the completed questionnaires

In general, more men than women, most of them younger, who are mainly among 19- and 24-years old, completed the questionnaires (Table 1).

We analysed our results visually therefore in the case of all seven settlements, we prepared a thematic map of the settlements, on which we marked the safe places with green colour and shades and then the unsafe places with red colour and shades. These areas were also places that were perceived differently by the respondents as some of them marked a site as safe and others as unsafe (Figure 2).

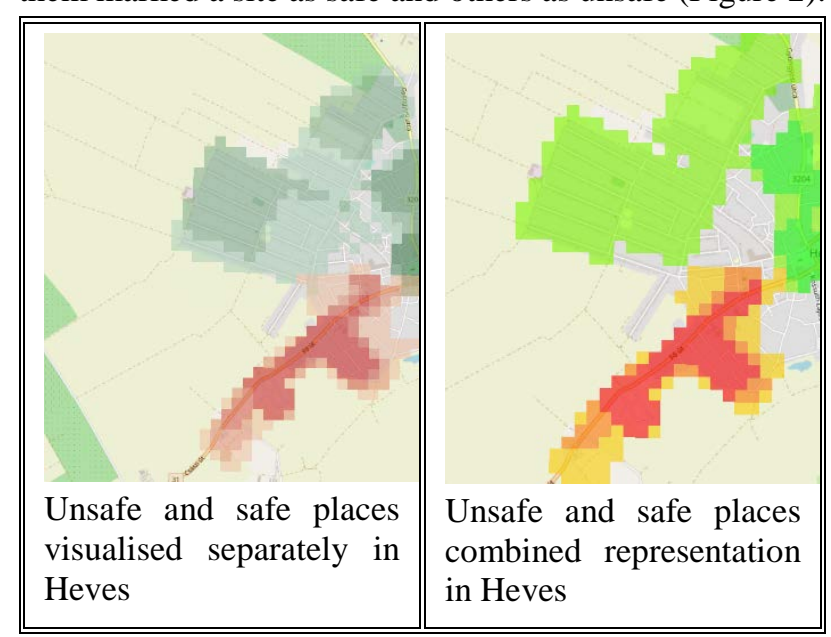

Figure 2. Representation of safe and unsafe areas on a thematic map in the case of Heves settlement

The completed thematic maps were visually analyzed. The analysis shows that in most settlements, the areas considered safe and unsafe are well separated, as shown in Figure 2. This is also supported by a study of the Moran's I index for each settlement. This is also important because the areas that perceived unsafe are in one area.
In the study, the clustering of the polygons obtained by the questionnaire achieved a very high result. For almost all safe and unsafe areas, the Moran's Indices were above 0.9, meaning we can say that they form spatially connected areas. On the other hand, this cannot be said about registered crime records, as even the highest Moran I's Index achieved only 0.57 in Budapest. We obtained values much lower in the other cities, between 0.1 and 0.3 , which indicates that the crimes occur in a scattered, not clustered manner.

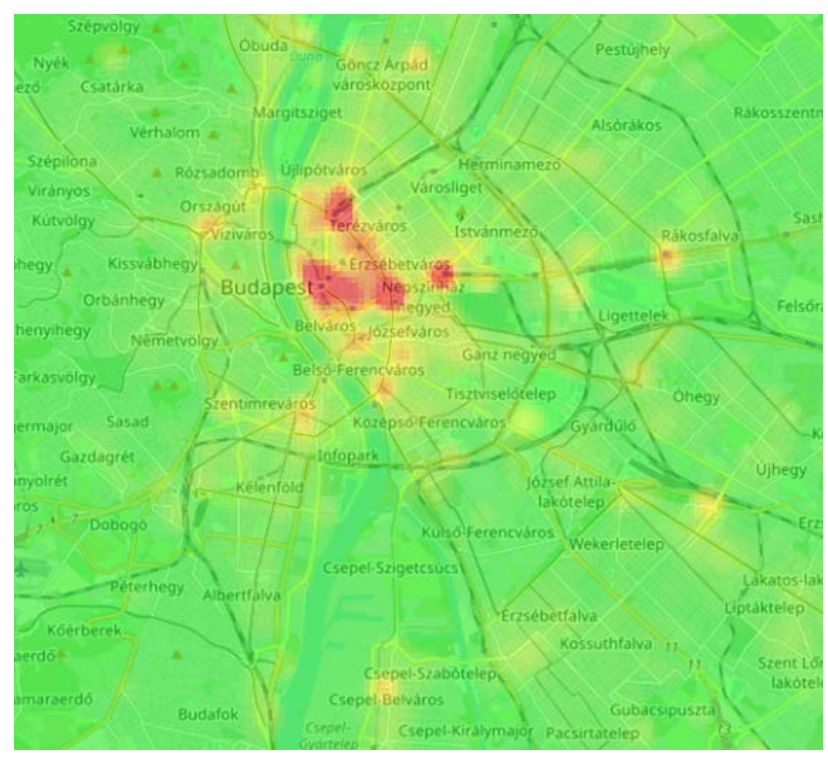

Figure 3. Kernel Density Map of Budapest (about registered crimes)

Kernel density (KDE), where we used the default search radius and parameters and hotspot analyses did not make a significant difference, so we created hotspots based on crimes visually projected onto unsafe locations.

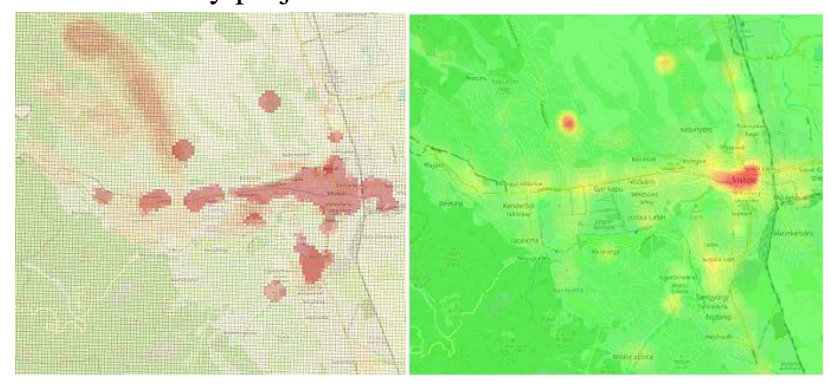

Figure 4. In the case of Miskolc, the hot spots (dark red) formed from the crime statistics, and the unsafe areas marked by the respondents (first map) are red.

As shown in Figure 4, there are areas where hotspots coincide with areas marked as unsafe by respondents for the seven settlements. However, some areas cannot be explained by the number of crimes. 


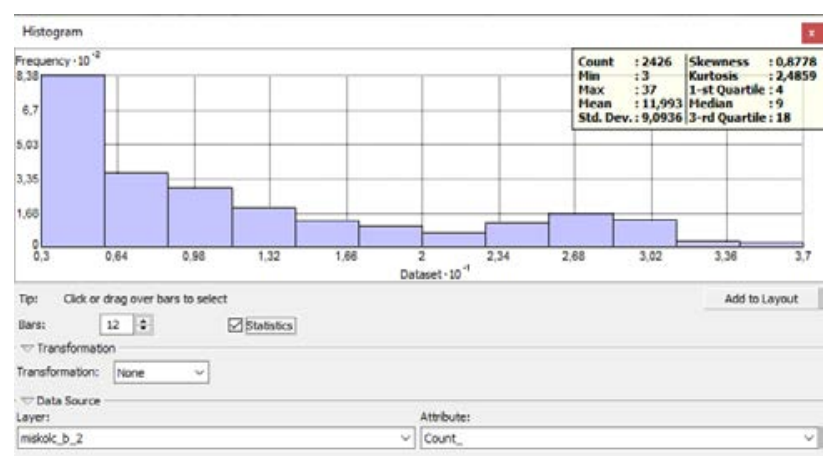

Figure 5. The histogram of safe places of Miskolc.

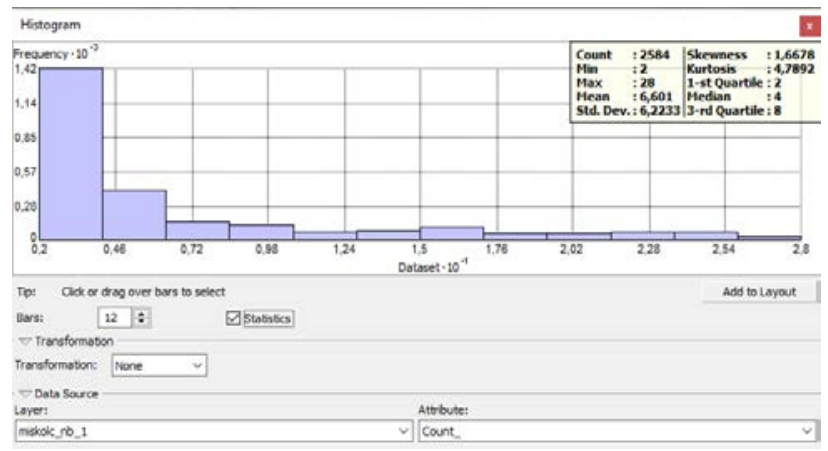

Figure 6. The histogram of unsafe places of Miskolc.

If we analyse the histogram (Figure 5, 6) of safe and unsafe places we can conclude that in the grid containing the number of overlapping polygons the majority contains one to 3 overlapping polygons, although there are areas where these number can reach as high as 50. While comparing the different settlements we cannot see any tendencies of the perceived safety and unsafety as in some places respondents marked more safe places on the other hand in case of other settlement the respondents marked twice as much unsafe places as safe places.

\section{Conclusions}

From the summary of the results, it can be concluded that, in general, crimes are scattered in most settlements. Areas held in frightening or safe ways usually have crimes that are designated with territorial differences. These types of online polls can help municipalities understand how they value citizens and the environment. Research shows that online questionnaires are suitable for feeling where an awesome area is located for multiple settlements with different structures. Problem areas may also be indicated by crime in statistics, but they do not always coincide. Of course, it is a fundamental goal for all municipalities to increase the population's subjective security, which is an excellent tool to provide these surveys.

\section{Acknowledgments}

The author thanks UNIGIS Hungary for its support.

\section{References}

Brantingham P, Brantingham P (2010) Criminality of place. Eur J Crim Policy Res 3(3):5-26

Brunton-Smith I, Sturgis P (2011) Do neighborhoods generate fear of crime? an empirical test using the British Crime Survey. Criminology 49(2):331-369

Chainey, S., \& Ratcliffe, J. (2013). GIS and crime mapping. John Wiley \& Sons.

Kanó, I. S. (2013). A gazdasági tevékenységek térbeli eloszlásának térképi megjelenítése magyar tudásintenzív ágazatok példáján. In: Területi Statisztika, 53(05), pp. 435-456.

Kounadi, O., Bowers, K., \& Leitner, M. (2015). Crime mapping on-line: Public perception of privacy issues. European journal on criminal policy and research, 21(1), 167-190

Leitner, M., \& Kounadi, O. (2015). Mapping fear of crime as a context-dependent everyday experience that varies in space and time. Legal and Criminological Psychology, 20(2), 218-221.

Mátyás Sz. (2017). A bünelemzés kartográfiai lehetőségei-avagy a bünözési térképek alkalmazása a mindennapi rendőri munka során. Pro Publico BonoMagyar Közigazgatás, 5(2), pp. 158-175.

Mátyás Sz., Sallai J., Vári V., Tihanyi M. Szarvák T (2020). Public Security as a Cooperative Activity a Few Thoughts on the Social and Public Image of Law Enforcement Work. In: Internal Security 12:1. pp. 35-44 https://internalsecurity.wspol.eu/resources/html/article/d etails?id=206623\&language=en

Mátyás Sz., Sallai J., Szarvák T., Tihanyi M., Vári V. (2019). Új paradigma felé: bizalom és biztonság a térben. 2019/2. In: Belügyi Szemle, pp. 22-44. https://ojs.mtak.hu/index.php/belugyiszemle/article/vie w/3537/2658

Pődör, A., Zentai, L., Gál, E. (2019). Digital sketch maps in teaching GIS for law enforcement students. Proc. Int. Cartogr. Assoc, 2, 102.

Pődör, A. (2015). Usability Study on Different Visualization Methods of Crime Maps. International Journal of Geoinformatics, 11(4).

Pődör, A., Dobos, M. (2014). Official crime statistics versus fear of crime of the citizens in a Hungarian small town. GI_Forum, pp. 272-275

Tihanyi, M., Mátyás, Sz., Vári, V., Krasnova, K., Volkova, M. (2020). Correlation Between Female Identity in Civil Society and Criminal Repression in Hungary and Russia. In: Russian Law Journal 8: 4 pp. 92-108. https://www.russianlawjournal.org/jour/article/view/108 4

Silverman, B. W. (1986). Density estimation for statistics and data analysis (Vol. 26). CRC Press.

Skogan WG, Maxfield MG (1981) Coping with crime: individual and neighborhood reactions. Sage Publications, Beverly Hills, CA, p 272 